\title{
Morphological and molecular identification of Phytophthora cinnamomi Rands as a causal agent of Crown and root rot in Blueberry (Vaccinium corymbosum) in Peru
}

\author{
Identificación morfológica y molecular de Phytophthora cinnamomi Rands como agente \\ causal de la pudrición de corona y raíces en arándanos (Vaccinium corymborum) en Perú.
}

\author{
Huarhua, M.; Flores, J.; Acuña, R.; Apaza W. ${ }^{1 *}$
}

*Corresponding author. wapaza@lamolina.edu.pe

\begin{abstract}
The Blueberry production in Peru has had rapid growth in the last five years, from having no area of more than 3050 hectares at present. As a result of this increase, many pathologic plant problems have appeared among them Phytophthora sp. causing plants with symptoms of wilt, reddish of lower leaves, regressive death, rotting of roots and crown of different production areas of Peru. However, there is no identification reported in Peru. Therefore, this study was conducted in the Plant Pathology Clinic of the Universidad Nacional Agraria La Molina with the objective of to identify the species of Phytophthora causing Crown and root rot isolated from blueberry in Peru. Four isolates from the blueberry's field were identified by morphological, molecular and pathogenically features. All the isolates formed corralled-type colonies with hyphal swelling on PDA and V-8 agar and produced obpyriform or ellipsoidal sporangia and globes chlamydospores. The internal transcribed spacer (ITS) of rDNA was amplified and sequenced with primer ITS1/ITS4 to confirm the identification, All the ITS nucleotide sequences from isolated obtained were submitted at GenBank of NCBI (Number Accession MH777152 to isolate AR-1, MH777151 to isolate AR-2, MH777150 to isolate AR-4, and MH777149 to isolate AR-3). Each one of the sequences showed $100 \%$ of homology with sequences of reference of P. cinnamomi in GenBank. Pathogenicity tests showed symptoms of redness and yellowing and root and Crown rot on Blueberry cv. Biloxi after 30 days of inoculation. Finally, concluded that $P$. cinnamomi is the species causing Crown and root rot in Blueberry in Peru. To our knowledge, this is the first report of $P$. cinnamomi on blueberry in Peru.
\end{abstract}

Keywords: Phytophthora cinnamomi, Blueberries, root rot, Crown rot, Molecular identification.

\section{Resumen}

La producción de arándanos en el Perú ha tenido un rápido crecimiento en los últimos cinco años, de no tener área alguna a 3050 hectáreas al presente. Como resultado de este crecimiento, han aparecido muchos problemas fitopatológicos entre ellos el ataque de Phytophthora sp. causando los síntomas de marchitez, enrojecimiento de hojas basales, muerte regresiva, pudrición de raíces y corona en las diferentes áreas de producción en el Perú. Si embargo, no existen reportes de la identificación de estos problemas en el Perú. Por lo tanto, este estudio fue realizado en la Clínica de enfermedades de plantas de la Universidad Nacional Agraria la Molina con el objetivo de identificar las especies de Phytophthora que causan la pudrición de corona y raíces del arándano en el Perú. Cuatro aislamientos de campos de arándano fueron identificados en forma morfológica y molecular, así como su característica de patogenicidad. Todos los aislamientos formaron colonias de tipo coraloide con hinchamientos hifales en medio PDA y Agar V-8 y produjeron esporangios piriformes o elipsoides y clamidosporas globosas. Los espacios intergénicos (ITS) de rDNA fueron amplificados y secuenciados con los iniciadores ITS1/ITS4 para confirmar la identificación. Todas las secuencias nucleotidas ITS de los aislamientos fueron enviados al GenBank de NCBI (Número de accesión MH777152 para el aislamiento AR-1, MH777151 para el aislamiento AR-2, MH777150 para el aislamiento AR-4, y MH777149 para el aislamiento AR-3). Cada una de las secuencias mostraron $100 \%$ de homología con las secuencias de referencias de P. cinnamomi en el GenBank. La prueba de patogenicidad mostro síntomas de enrojecimiento, amarillamiento y pudrición de raíces y corona en plantas de arándano cultivar Biloxi después de 30 días de inoculado. Finalmente, se concluye que P. cinnamomi es la especie que causa la pudrición de corona y raíces de arándano en el Perú. Este es el primer reporte de P. cinnamomi en el arándano en el Perú.

Palabra clave: Phytophthora cinnamomi, arándanos, pudrición de raíces, pudrición de corona, Identificación molecular 


\section{Introduction}

The blueberry belongs to the family of berries and has high growth prospects in the international market, due to its nutritional characteristics, because it contains an essential number of antioxidants. In Peru, Blueberry start to be cultivated between 2007-2008. By the year 2016, the cultivated blueberry area was estimated at 3050 hectares, with a production of 26.6 thousand tons, which is almost wholly exported (MINAGRI, 2016).

The implementation of more areas of blueberry crops is required to satisfy the national and international demand. However, one of the factors that limit this objective is the development of diseases that negatively affect the production. The most important disease is the root rot caused by oomycetes of the genus Phytophthora, it produces a gradual decay that eventually, lead to death all the prostrate shrubs (Toapanta-Gallegos et al., 2017).

Since 2011, to the Plant Pathology Clinic of the Universidad Nacional Agraria La Molina, have arrived blueberry plants of the Biloxi variety with symptoms of root rot of different production areas on the coast of Peru: Chavimochic, Lambayeque, Chongoyape, Cañete, Lunahuana, Chincha, Ica and Pisco.

Symptoms include loss of vigor, yellowing and foliar redness, defoliation and root rot. In the plants with advanced symptoms of the disease, there is rottenness of the neck, regressive death and finally the death of the plants. Reports from other countries indicate that this disease caused by Phytophthora cinnamomi (Polashock et al., 2017).

The objective of this research is to identify Phytophthora species that affect blueberry crops from different regions of Peru, for which it is necessary to perform morphological, molecular and pathogenicity tests to confirm its presence.

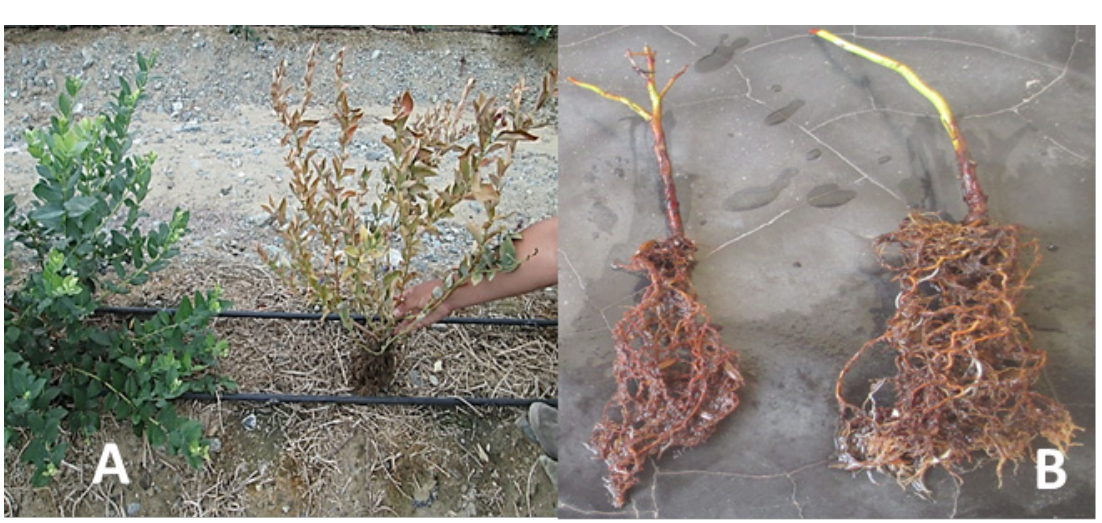

Figure 1. A: Blueberry plants with symptoms of yellowing and foliar redness. B: Blueberry plants with advanced symptoms of root and neck rot.

Table 1. Isolates of Phytophthora sp. obtained from Blueberry (Vaccinium sp.) from Peru

\begin{tabular}{ccc}
\hline Isolate & Source & Locality \\
\hline AR-1 & Crown/ Roots & Lima- Cañete \\
AR-2 & Crown/ Roots & Ica -Pisco \\
AR-3 & Crown/ Roots & Lima- Cañete \\
AR-4 & Crown/ Roots & La Libertad - Chavimochic \\
\hline
\end{tabular}

\section{Material and Methods}

\section{a) Isolates}

The isolates of Phytophthora were obtained from roots of blueberry plants collected from commercial fields located in Cañete, Pisco, Lima, Chavimochic (Table 1). The plants showed leaf chlorosis, foliage reddening, dieback, root and Crown rot (Figure 1). The samples were processed in the Plant Pathology Clinic lab of the Universidad Nacional Agraria La Molina. The root and crown were washed thoroughly under abundant tap water. Portions of roots and crown with lesion were cut into small pieces, superficial tissue was disinfected in $70 \%$ ethanol for 5 seconds after that, each sample was disinfected with $1 \%$ sodium hypochlorite solution for 5 minutes and then washed for twice in sterile distilled water (SDW) (Dhingra et al., 1995), then dried on sterile paper. Crown and root pieces, about 4- $10 \mathrm{~mm}$-wide at the junction of the healthy and necrotic tissue were placed on PARB (10 mg pimaricin, $250 \mathrm{mg}$ ampicillin, $10 \mathrm{mg}$ rifampicin, and $20 \mathrm{mg}$ Benomyl) selective medium. The plates were incubated at $24^{\circ} \mathrm{C}$ for three days in darkness (Erwin and Ribeiro, 1996). The pure cultures of the fungus were obtained from a hyphal tip.

\section{b) Morphological and Cultural Characterization}

Each Isolate on PARB was transferred on Potato dextrose agar (PDA) and V8 Juice agar (V-8) to evaluate the growth of characters. Petri plates with $20 \mathrm{ml}$ of each medium were inoculated with $7 \mathrm{~mm}$ disc cut from mycelium pieces taken from an actively growing colony on PARB and incubated at $24{ }^{\circ} \mathrm{C}$ for 7 days. Each treatment was replicated four times. Observations cultural colony pattern were recorded at seven days after inoculation following the descriptions of Erwin and Ribeiro (1996).

Sporangia were produced by cutting 5-mm-diameter disks from the advancing margin of a colony grown on PDA and V8, floating these disks on $10 \mathrm{ml}$ of $1 \%$ non-sterile soil extract solution $(\mathrm{w} / \mathrm{v})$ for $4-5$ days at $24{ }^{\circ} \mathrm{C}$ under continuous light from fluorescent lamps (Erwin and Ribeiro, 1996). After $72 \mathrm{~h}$, hyphal portions were mounted in $\mathrm{KOH}$ at $3 \%$ and observed microscopically at $400 \mathrm{X}$ magnification (Leica DM 1000 LED microscope).

For each isolate: shape, length (L) and breadth (B) of 50 sporangia were measured, and was calculated length to breadth ratio (L/B). Additionally, were taken sporangiophore breadth, chlamydospore diameter, and swelling hyphal measurements.

\section{c) Pathogenicity test}

The pathogenicity method was for 
inoculation of soil. This method is convenient for species of Phytophthora, which do not readily sporulate such as Phytophthora cinnamomi (Drenth and Barbara, 2001).

For the production of inoculum was boiled a natural substrate of wheat in distilled water for 8 minutes. Then the excess water was removed and left to dry then it was bagged $200 \mathrm{gr}$ in polypropylene bag for autoclaving at $121^{\circ} \mathrm{C}$ for 50 minutes on two consecutive days. After that, the bags were inoculated with two small discs of agar containing mycelium and incubate at $24^{\circ} \mathrm{C}$ for three weeks. The mixture was shaking every 2 days to obtain an even spread of Phytophthora mycelium throughout the substrate.

Two-month-old Blueberry plants were transplanted to a plastic ball with $1 \mathrm{~kg}$ of an autoclaved soil mixture of sand, rice husk and peat (In relation 1:1:1). One month later, the plants were inoculated with 20 wheat seeds with mycelium, it was added on the substrate around to the neck into each plant and was covered by the same substrate at $1 \mathrm{~cm}$, immediately was put sterile water to the inoculation and was maintained the humidity of the substrate.

\section{c) Molecular characterization}

To extract genomic DNA the oomycete was cultivated on potato dextrose agar for five days at $25^{\circ} \mathrm{C}$. The extraction of genomic DNA was carried out in triplicate for each evaluated isolation, following the protocol of ZelayaMolina et al. (2011) with some modifications. A mycelium block about $5 \mathrm{~mm}$ in diameter was cut and placed in $1.5 \mathrm{ml}$ Eppendorf tubes. Five hundred microliters of lysis buffer (100 mM Tris $\mathrm{HCl}, 10 \mathrm{mM}$ ethylenediaminetetraacetic acid [EDTA], 1M KCl; pH 8.0) was added and mix well with the pestle. Then, chloroform/isoamyl alcohol $(24: 1, \mathrm{v} / \mathrm{v})$ were added, the tube was vortexed until the two phases formed an emulsion and centrifuged for $10 \mathrm{~min}$ at 12000 rpm. The supernatant was transferred to a $1.5 \mathrm{ml}$ tube. To precipitate the DNA, $1 \mathrm{ml}$ isopropanol was added. The tube was inverted five times and held at $-20^{\circ} \mathrm{C}$ for $15 \mathrm{~min}$. A DNA pellet was formed by centrifugation for $10 \mathrm{~min}$ at $12000 \mathrm{rpm}$. The supernatant was carefully discarded, and the pellet was washed with $1 \mathrm{ml}$ of $70 \%(\mathrm{v} / \mathrm{v})$ ethanol. The tube was then placed upside down over a paper towel for 2 hours or until the pellet was dried entirely. The pellet was resuspended in $30 \mu \mathrm{l}$ of TE buffer $(100 \mathrm{mM}$ Tris/ $\mathrm{HCl}, \mathrm{pH}$ 8.0, $10 \mathrm{mM}$ EDTA) and stored at $-20^{\circ} \mathrm{C}$.

The DNA concentrations were quantitatively determined using the Nanodrop spectrophotometer (Nanodrop 2000). Also, it was qualitatively determined by performing electrophoresis for 30 minutes at $90 \mathrm{~V}$ on the agarose gel stained with hydragreen.

For the development of the polymerase chain reaction, the universal primers ITS 1 (TCCGTAGGTGAACCTGCGG) and ITS 4 (TCCTCCGCTTATTGATATGC) were used to amplify the rDNA nuclear region of internal transcribed spacers (ITS), including 5,8S rDNA, as described by White et al. (1990). The total $25 \mathrm{ul}$ reaction mixture contained $1 \mathrm{ul}$ of genomic DNA of $50 \mathrm{ng}, 4 \mathrm{ul}$ of 10X PCR Buffer (ACTaq TM), 2 ul of each $2.5 \mathrm{mM}$ dNTPs (ACTaq $\left.{ }^{\mathrm{TM}}\right), 0.125 \mathrm{ul}(5$ $\mathrm{U})$ of Taq enzyme DNA polymerase (ACTaq ${ }^{\mathrm{TM}}$ ) and $0.5 \mathrm{ul}$ of each primer of $20 \mathrm{mM}$.

The amplifications were carried out with a thermocycler (Thermo Scientific) with the following parameters: Initial denaturation of $94{ }^{\circ} \mathrm{C}$ during $2 \mathrm{~min}$; followed by 35 cycles of denaturation at $98{ }^{\circ} \mathrm{C}$ for $1 \mathrm{~min}$, annealing at $58{ }^{\circ} \mathrm{C}$ for $1 \mathrm{~min}$, and elongation at $72{ }^{\circ} \mathrm{C}$ for $2 \mathrm{~min}$, and a final extension at $72{ }^{\circ} \mathrm{C}$ for $10 \mathrm{~min}$. The PCR products have a size of $850 \mathrm{bp}$. These were separated by electrophoresis with $0.5 \mathrm{X}$ TAE buffer in $2 \%$ agarose gels for $30 \mathrm{~min}$ at $90 \mathrm{~V}$ and stained with hydragreen. The observation of the fragments was using a transilluminator of ultraviolet light (UVP brand). 100bp DNA Ladder (Promega) was used as a reference. Fragments amplified by PCR were sequenced in both directions in Macrogen-Korea and compared with the gene bank database of the National Center for Biotechnology Information (NCBI).

\section{d) Analysis of sequences and Phylogenetic Analyses}

The sequences obtained were assembled, aligned and edited using Codon Code Aligner 8.0.2 program (CodonCode Aligner, USA). All sequences obtained in this study were compared with those on GenBank using "BLASTn" (http://www.ncbi.nlm.nih.gov/blast/). ClustalW nucleotide sequence alignments (Thompson et al., 1994) and Neighbor Joining (NJ) clustering analysis were performed using MEGA5. NJ trees employed the Kimura-2-Parameter (K2P) distance model (Kimura, 1980) with pairwise deletion of missing sites and nodal support was estimated using 500 bootstrap replicates. Some sequences of genus Phytophthora obtained from the GenBank were considered in the phylogenetic analysis: GenBank AY995407.1 of Phytophthora megasperma, GenBank KP676165.1 of Phytophthora citrophthora and GenBank MF536298.1, GenBank KF271786.1, GenBank KC478665.1, GenBank EF055303.1, GenBank AY302149.1, GenBank MG560191.1, GenBank KC478663.1, GenBank KC184904.1, GenBank KF559323.1, GenBank DQ173250.1 of Phytophthora cinnamomi. Fusarium oxysporum (GenBank AY387701.1) was used as an outgroup to phylogenetic analysis.

\section{Results and Discussion}

\section{Morphological and cultural characterization}

Based on cultural characteristics of the colony and morphometric evaluation of asexual reproduction structures. Phytophthora cinnamomi was identified in the four isolates.

Cultural patterns of AR-1, AR-2, AR-3, AR-4 isolates obtained on PDA medium formed colonies with a cottonlike aspect, white colored and growth pattern rose-type. In the V-8 medium, the colonies were similar to those obtained in PDA medium, but with the less marked rosette growth pattern (Figure 2). This typical growth is described 
by Mehrlich (1935), who mentions that the colony of Phytophthora cinnamomi in PDA has a pattern similar to the petals of a rose or camellia flower, further references that this morphology feature is unique for this species. Thus, this characteristic of rose -type growth is typical of P. cinnamomi according to Erwin and Ribeiro (1996).

According to the morphological characteristics in PDA and V-8 media, the growth of coenocytic hyphae typical of pseudo-fungi of the family Pythiaceae was evidenced. Besides, a coralloid mycelium, with abundant hyphal swellings and rounded chlamydospores with a thin wall forming clusters. Likewise, in the soil solution, the formation of numerous zoosporangia was observed from an obpyriform to an ellipsoid shape with presence of an

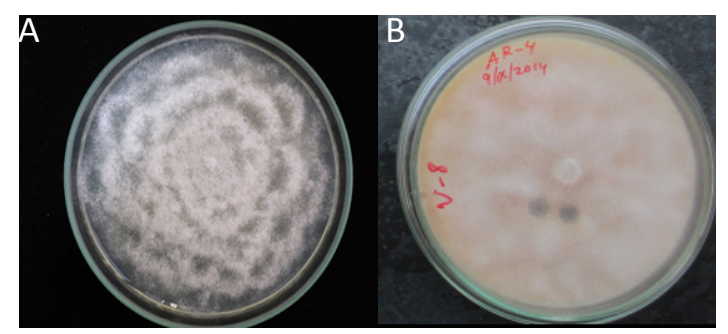

Figure 2. Phytophthora cinnamomi isolates exhibiting rosaceous colony morphology on potato dextrose agar (A) and V-8 medium (B).
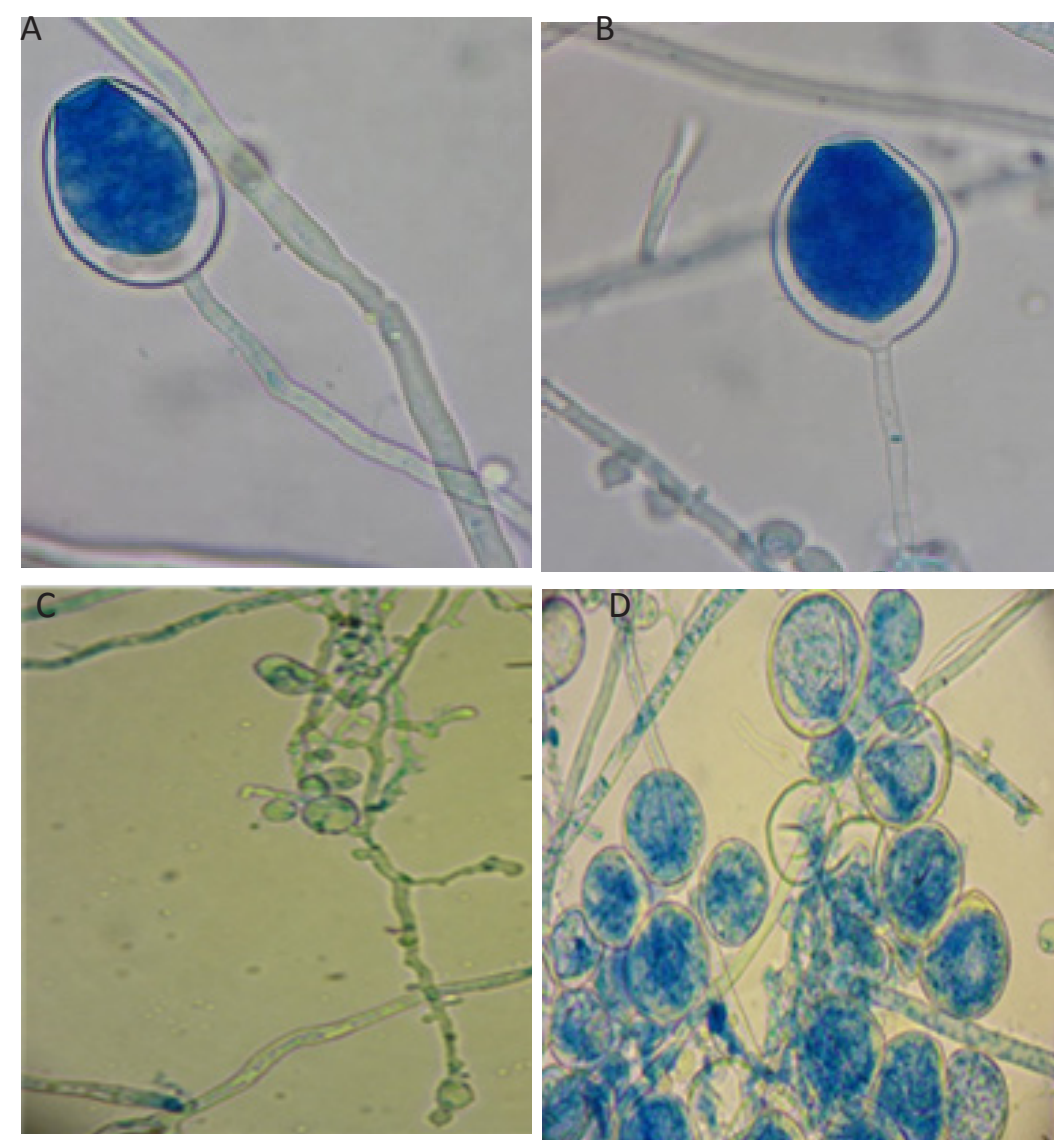

Figure 3. Morphological feature dyed with cotton blue of Phytophthora cinnamomi isolated from Blueberry. Obpyriform to ellipsoids sporangia without papillae with long pedicels (A-B), Coralloid type mycelium with Hyphal swellings (C), chlamydospores (D). apical pore, a wide pore without papilla formation, which at the time of maturity released numerous zoospores, the thin, long and generally simple sporangiophore (no branching), no oospore formation was observed (Figure 3). These characteristics are similar in the four isolates and are related to Phytophthora cinnamomi (Erwin and Ribeiro, 1996; Huaman et al., 2015; Drenth and Barbara, 2001; Ho and Zentmyer, 1977; Larach et al., 2009).

Regarding the characteristics in measure in the four isolations were the following: the zoosporangia oscillated 49-57 x 35-40 um in length and width respectively, the ratio length/width (L/A) varied between 1.36 to 1.43 , with a pedicel thickness from 3 to $3.5 \mathrm{um}$, chlamydospores were between 40-43 um in diameter and hyphal swellings (HH) from 22 to $28 \mathrm{um}$ in each of the isolates (Table 2). Due to the characteristics of the asexual structures of these fungi, it was shown that they were Phytophthora cinnamomi, which conform to those described by Erwin and Ribeiro (1996), Gallegly and Chuanxue (2008), Waterhouse and Waterston (1996) and Polashock et al. (2017) for the species Phytophthora cinnamomi.

\section{Pathogenicity Test}

All the isolates identified as Phytophthora cinnamomi in the morphological and molecular tests turned out to be pathogenic in the blueberry culture. Likewise, in the PARB medium, it was possible to re-isolate the pathogen under study from the diseased tissues, which shows the success of Koch's postulate. The symptoms observed in the inoculated plants began to be found after 30 days with foliar yellowing after 30 days, and foliar redness after 45 days; also, rot symptoms were observed at the root and neck levels of the plant (Figure 4). On the other hand, the control plants did not show any symptoms in the foliar system, at the level of the neck or roots. These symptoms coincide with the symptoms developed in blueberry fields in the evaluated areas of Peru, as well as with the symptoms described for Phytophthora cinnamomi in different parts of the world (Lan et al., 2016; Shands et al., 2016).

\section{Molecular Identification}

Before the revolution of molecular biology, fungi and oomycetes were identified morphologically. Nowadays with the advance of technology, the study of microorganisms through their DNA has many applications including the identification of species, the observation of the relationships between groups of organisms, even the detection of pathogens in water and soil without resorting to isolation in culture medium (Cooke et al., 2000). 
Table 2. Morphometric characteristics of 4 isolates of Phytophthora cinnamomi isolated from blueberry plants with symptoms of root rot.

\begin{tabular}{|c|c|c|c|c|c|c|c|}
\hline \multirow[t]{2}{*}{ Isolates } & \multirow[t]{2}{*}{$\begin{array}{c}\text { sporangia } \\
\text { (um) } \\
\text { Lx B }\end{array}$} & \multirow[t]{2}{*}{$\begin{array}{l}\text { Ratio } \\
\text { L/B }\end{array}$} & \multirow[t]{2}{*}{$\begin{array}{l}\text { zoosporangia } \\
\text { breadth (um) }\end{array}$} & \multirow[t]{2}{*}{$\begin{array}{c}\text { chlamydospore } \\
\text { (um) }\end{array}$} & \multirow[t]{2}{*}{$\begin{array}{l}\mathrm{SH} \\
\text { (um) }\end{array}$} & \multicolumn{2}{|c|}{$\begin{array}{c}\text { Colony } \\
\text { diameter } \\
(\mathrm{mm}) \text { a } 3 \\
\text { days }-24^{\circ} \mathrm{C}\end{array}$} \\
\hline & & & & & & PDA & V-8 \\
\hline AR-1 & $\begin{array}{c}57 \times 40 \\
(38-75 \times 28-50)\end{array}$ & 1.43 & 3.1 & $\begin{array}{c}40 \\
(30-50)\end{array}$ & 28 & 39 & 45 \\
\hline AR-2 & $\begin{array}{c}49 \times 35 \\
(43-63 \times 28-40)\end{array}$ & 1.40 & 3.3 & $\begin{array}{c}40 \\
(33-60)\end{array}$ & 22 & 38 & 43 \\
\hline AR-3 & $\begin{array}{c}50 \times 37 \\
(43-55 \times 33-40)\end{array}$ & 1.36 & 3.0 & $\begin{array}{c}43 \\
(30-53)\end{array}$ & 22 & 37 & 42 \\
\hline AR-4 & $\begin{array}{c}52 \times 38 \\
(38-60 \times 25-48)\end{array}$ & 1.37 & 3.5 & $\begin{array}{c}40 \\
(35-50)\end{array}$ & 23 & 39 & 44 \\
\hline
\end{tabular}

L/B =Length/Breadth zoosporangia $\mathrm{SH}=$ Swelling Hyphal

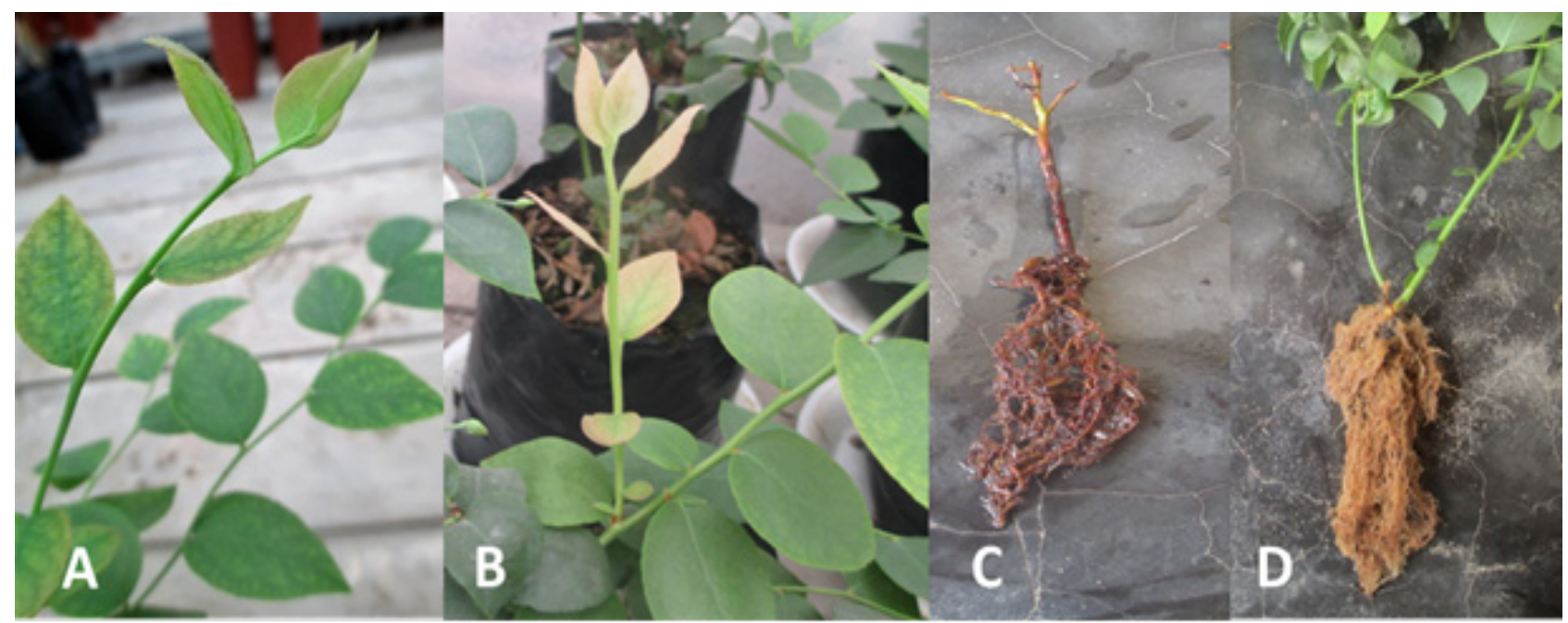

Figura 4. Pathogenicity test on Blueberry plants inoculated with Phytophthora cinnamomi. chlorosis (A), foliar reddening (B), crown and root rot (C) and root system without inoculation (D).

The extraction of genomic DNA from the AR-1, AR2, AR-3, and AR-4 isolates, morphologically identified as Phytophthora cinnamomi, had a yield higher than $50 \mathrm{ng}$ for each sample and the quality was more significant than 1.9 in the $260 / 230$ ratio. The quality of the extraction can be observed in Figure 5.

The polymerase chain reaction (PCR) technique is a system that allows obtaining several million copies of DNA sequence to facilitate the diagnosis of a particular species (Rodríguez and Barrera, 2004). With the use of ITS primers, a $900 \mathrm{bp}$ fragment was amplified in the four isolates (Figure 6). They were achieved without the presence of nonspecific bands. So, they were sent directly to sequencing.

The nucleotide sequences were edited using Codon Code Aligner. The sequences edited were aligned by Blast with the data of $P$. cinnamomi sequences stored in GenBank. The percentage of similarity was at $100 \%$ to $P$. cinnamomi to each one of the sequences AR-1, AR-2, AR3 , and AR-4.

By comparing and aligning the sequences of the AR-1, AR-2, AR-3 and AR-4 isolates with other P. cinnamomi sequences from different cultures, from different regions, and with other species of the genus Phytophthora, a phylogenetic tree was created (Figure 7).

The tree was inferred using the Maximum Likelihood method based on the Jukes and Cantor (1969) model). The tree is drawn to scale, with branch lengths measured in the number of substitutions per site. The analysis involved 21 nucleotide sequences.

The AR-1, AR-2, AR-3 and AR-4 sequences (shaded in gray) in figure 6 were grouped in the same clade with the P. sequences from different cultures. Likewise, the sequences of the isolates AR-1, AR-2, AR-3, and AR-4 were separated in the distance from $P$. megasperma, $P$. infestans, $P$. citrophthora and had greater separation with Fusarium oxysporum as an external group (Figure 7). These results corroborate the identification of the isolates as part of the species $P$. cinnamomi.

When comparing the ITS nucleotide sequences region of the four blueberries Phytophthora cinnamomi isolates (AR-1, AR-2, AR-3, and AR-4), they all showed the same nucleotide sequence; therefore, we can infer that these isolates corresponded to clones of the same isolation which 


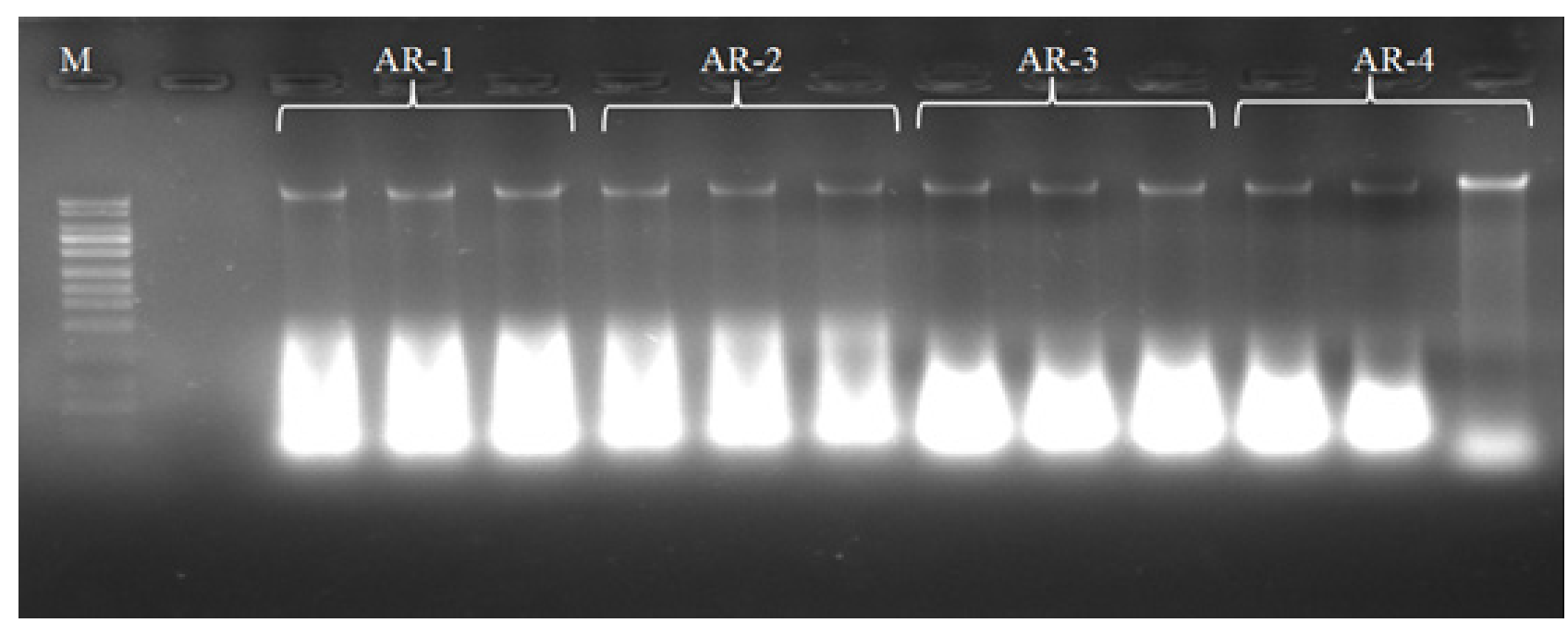

Figure 5. Agarose gel electrophoresis results of genomic DNA extracted from Blueberry samples. M: Molecular -weight markers (High Ranger 1Kb DNA Ladder, NORGEN), AR-1, AR-2, AR-3 y AR-4 isolates from Cañete, Pisco, Cañete and Chavimochic, respectively.

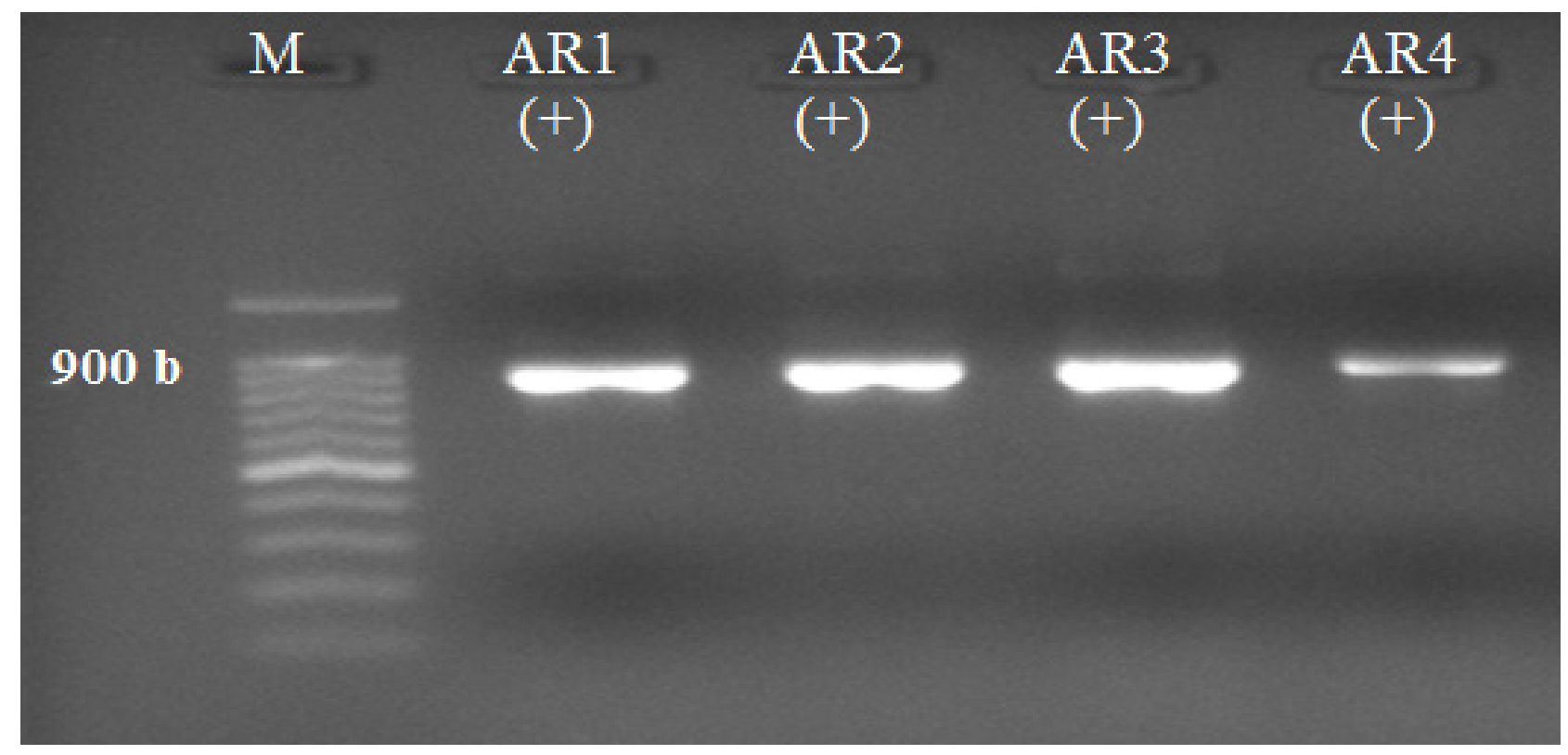

Figure 6. Result of gel electrophoresis of PCR product using ITS 1/ITS4 primers. M: Molecular -weight markers (100bp DNA Ladder, PROMEGA), AR-1, AR-2, AR-3 y AR-4 isolates from Cañete, Pisco, Cañete and Chavimochic, respectively.

is present in the four provinces sampled (Cañete, Pisco, Lima, and Chavimochic).

The sequence was deposited in the GenBank gene bank with accession number MH777152 to isolate AR-1, MH777151 to isolate AR-2, MH777150 to isolate AR-4, and MH777149 to isolate AR-3. Similarly, according to the grouping arrangement in the tree, it is concluded that there are no genetic differences between the isolates of other $P$. cinnamomi from Peru for different populations of $P$. cinnamomi from other countries. This result corroborates the highly conserved nature of the ITS region for the species P. cinnamomi, and the low efficiency of the endpoint PCR technique to discriminate different populations of the same species to establish patterns that explain processes of diversification (Garzon, 2013).

\section{Conclusions.}

In conclusion, from morphological, cultural, molecular and pathological analyses, the causal agent of root and crown rot causing wilting and decline of blueberry trees was identified as Phytophthora cinnamomi. To our knowledge, this is the first report of $P$. cinnamomi on blueberry in Peru.

\section{Acknowledgements}

Dr. Blas and Joel Flores of the Institute of Biotechnology (IBT) of the National Agrarian University La Molina.

\section{References}

Cooke, D. E., Drenth, A., Duncan, J. M., Wagels, G. 


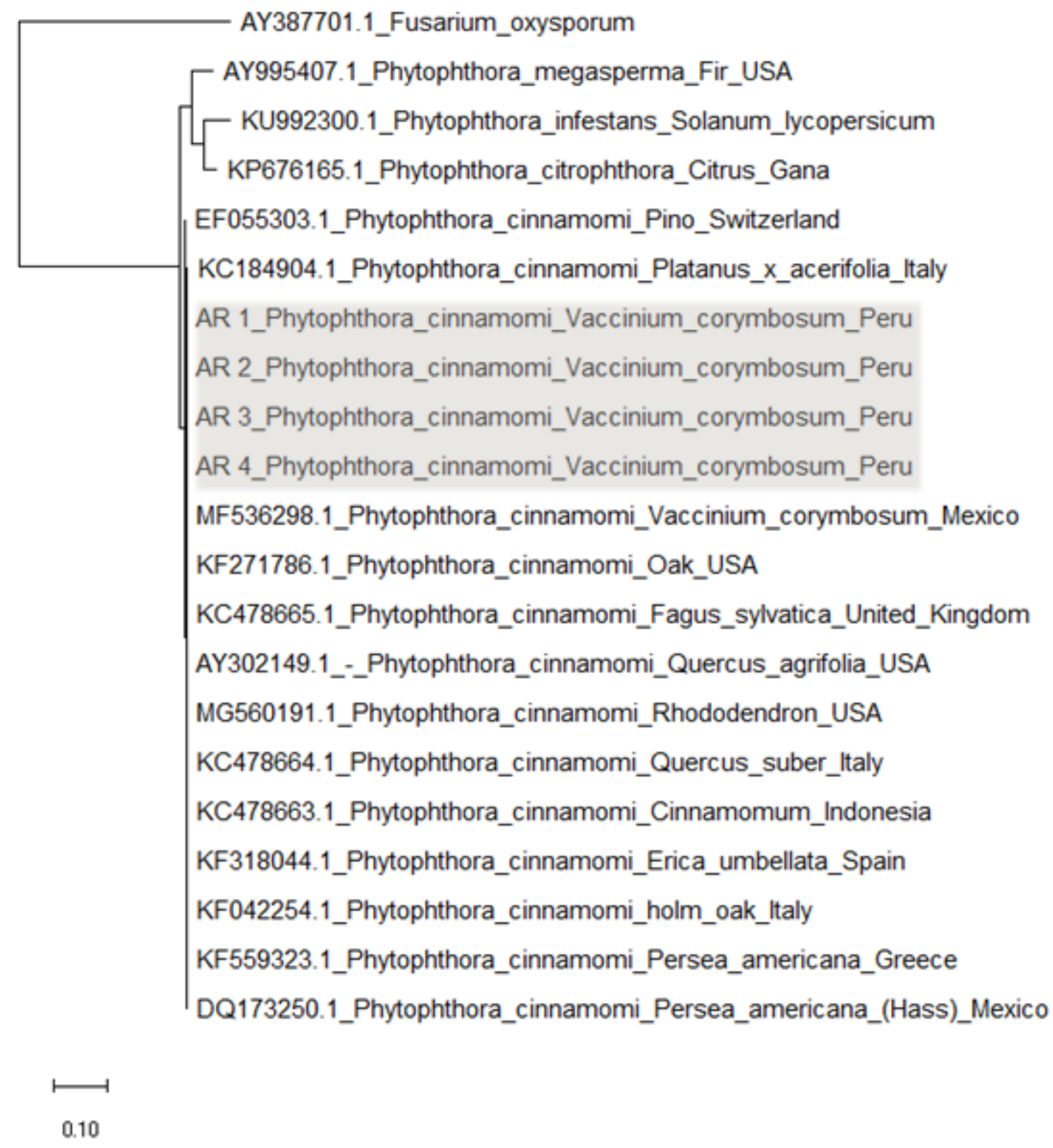

Figure 7. Molecular Phylogenetic analysis by Maximum Likelihood method of AR-1, AR-2, AR-3 and AR-4 isolates belong to Phytophthora cinnamomi group.

and Brasier, C. M. 2000. A molecular phylogeny of Phytophthora and related oomycetes. Fungal Genetics and Biology, 30(1): 17-32. https://doi.org/10.1006/ fgbi.2000.1202

Dhingra, O. and Sinclair, J. 1995. Basic Plant Pathology Methods, CRC Press, U.S.A. Second edition. 435 p.

Drenth, A. and Barbara, S. 2001. Practical guide to detection and identification of Phytophthora. CRC for Tropical Plant Protection 1:1-41.

Erwin, D. C. and Ribeiro, O. 1996. Phytophthora Diseases Worldwide, APS press, U.S.A. 562 p.
Gallegly, M. E. and Chuanxue Hong. 2008. Phytophthora identifying Species by Morphology and DNA Fingerprints. APS press, U.S.A. 158 p.

Garzon, N. 2013. Caracterización e identificación molecular de hongos de suelo aislados de los páramos de Guasca y Cruz verde, Cundinamarca - Colombia. Pontificia Universidad Javeriana. Tesis de Pregrado.

Ho, H., and Zentmyer, G. 1977. Morphology of Phytophthora cinnamomi. Mycologia 69(1):701-713. Doi: $10.2307 / 3758860$

Huaman, N., Valeriano, J., and Granados, E. 2015. 
Aislamiento e identificación de Phytophthora cinnamomi Rands en el cultivo de palto variedades Hass y Fuerte. CienciAgro Journal of Agricultural Science and Technology, 1:57-63.

Jukes, T.H. and Cantor C.R. 1969. Evolution of protein molecules. In Munro HN, editor, Mammalian Protein Metabolism, pp. 21-132, Academic Press, New York.

Kimura, M. 1980. Simple method for estimating evolutionary rates of base substitutions through comparative studies of nucleotide sequences. Journal of Molecular Evolution; 16(2): 111-120. https://doi. org/10.1007/BF01731581

Kumar, S., Stecher G., Li, M., Knyaz, C. and Tamura, K. 2018. MEGA X: Molecular Evolutionary Genetics Analysis across computing platforms. Molecular Biology and Evolution 35:1547-1549. Doi: 10.1093/ molbev/msy096.

Lan, C., Ruan, H. and Yao, J. 2016. First Report of Phytophthora cinnamomi Causing Root and Stem Rot of Blueberry (Vaccinium corymbosum) in China. Plant Disease 100: 2537. https://doi.org/10.1094/PDIS-0316-0345-PDN

Larach, A., Besoain, X. and Salgado, E. 2009. Crown and root rot of highbush blueberry caused by Phytophthora cinnamomi and $P$. citrophthora and cultivar susceptibility. Ciencia e Investigación Agraria 36(3):433-442. $\quad$ https://doi.org/10.4067/S071816202009000300010 .

Mehrlich, F.1935. Nonsterile soil leachate stimulating to zoosporangia production by Phytophthora sp. Phytopathology 25, 432-434.

MINAGRI. Ministerio de Agricultura y Riego. 2016. El Arándano en el Perú y el Mundo.

Ochoa-Fuentes, Y., Cerna, E., Landeros, J., Vazquez, O., Olalde, V. and Flores, A. 2009. Diversidad genética de Phytophthora cinnamomi Rands de aguacate de Michoacán, México, por medio de RAPD. Phyton (Buenos Aires), 78(1), 25-30.

Polashock, J. J., Caruso, F., Averill, A. and Schilder, A. 2017. Compendium of Blueberry, Cranberry, and Lingonberry Diseases and Pests, APS press, U.SA. Second Edition. 231 p.

Rodríguez, I. and Barrera, H. 2004. La reacción en cadena de la polimerasa a dos décadas de su invención. Ciencia UANL 3:3

Shands, A., Yamagata, J., Wright, A., and Miles, T. 2016. First Report of Phytophthora cinnamomi Causing Root Rot of Southern Highbush Blueberry In California. Plant Disease 100(2): 537. https://doi.org/10.1094/ PDIS-07-15-0738-PDN

Tamura, K., Peterson, D., Peterson, N., Stecher, G., Nei, M., Kumar, S. 2011.MEGA5: molecular evolutionary genetics analysis using maximum likelihood, evolutionary distance, and maximum parsimony methods. Molecular Biology and Evolution 28: 2731-

\section{Doi: 10.1093/molbev/msr121 PMID: 21546353}

Thompson, J., Higgins, D., Gibson, T.1994. Clustal W: improving the sensitivity of progressive multiple sequence alignment through sequence weighting, position-specific gap penalties and weight matrix choice. Nucleic Acids Research 22:4673-4680.

Toapanta-Gallegos, D., Morillo-Velastegui, L. and Viera-Arroyo, W. 2017. Diagnóstico molecular de Phytophthora cinnamomi asociado a la pudrición radicular en zonas productoras de aguacate en Ecuador. Corpoica Ciencia y Tecnología Agropecuaria 18(2): 285-294. http://dx.doi.org/10.21930/rcta.vol18 num2 art:628

Waterhouse, G. and Waterston, J. 1966. CMI Descriptions of Pathogenic Fungi and Bacteria, England. 113:1-2. (113):1-2

Drenth, A. and Barbara, S. 2001. Practical guide to detection and identification of Phytophthora. Tropical Plant Protection, 1-41.

Zelaya-Molina, L. X., Ortega, M. A. and Dorrance, A. E. 2011. Easy and efficient protocol for oomycete DNA extraction suitable for population genetic analysis. Biotechnology Letters, 33(4), 715-720. https://oi. org/10.1007/s10529-010-0478-3 